\title{
Efek ASI Eksklusif terhadap Stunting pada Anak Usia 6-59 bulan di Kabupaten Bogor tahun 2019
}

\section{Impact of Exclusive Breastfeeding on Stunting among Child Aged 6-59 Months in Kabupaten Bogor at 2019}

\author{
Hardya Gustada Hikmahrachima, Rinawati Rohsiswatmo ${ }^{\text {, }}$ Sudarto Ronoatmodjoc ${ }^{\star}$ \\ Program Studi Magister Epidemiologi, Fakultas Kesehatan Masyarakat Universitas Indonesia, Depok 16424, Indonesia \\ Departemen Ilmu Kesehatan Anak FKUI RSCM \\ $c^{\star}$ Departemen Epidemiologi, Gedung A lantai 1 Fakultas Kesehatan Masyarakat Universitas Indonesia, Depok 16424, Indonesia
}

\section{A B S TR A K}

Stunting, atau perawakan pendek, berhubungan erat dengan hambatan kemampuan kognitif dan kualitas hidup. Prevalensi stunting di Indonesia mencapai 30,8\% tahun 2018. Stunting dipengaruhi pemenuhan nutrisi di awal kehidupan, salah satunya melalui ASI eksklusif. Meskipun cakupan ASI eksklusif di Indonesia sudah 74,5\%, hubungan stunting dengan ASI eksklusif seringkali tidak konsisten akibat keberagaman kuantitas dan kualitas ASI Penelitian ini ingin mengetahui efek ASI eksklusif terhadap stunting di Kabupaten Bogor, sebagai salah satu daerah tinggi stunting di Indonesia. Penelitian dengan desain potong lintang ini dilaksanakan di Puskesmas Kecamatan Ciampea, Kabupaten Bogor, pada Februari sampai April 2019. Kriteria inklusi adalah balita usia 6-59 bulan yang berkunjung ke poliklinik. Informasi pemberian ASI eksklusif diperoleh dari wawancara terstruktur, sementara stunting ditetapkan dengan antropometri terstandar. Dari 162 balita, 117 (72,22\%) mendapat ASI eksklusif dan 64 subjek (39,51\%) mengalami stunting. Pada analisis multivariat, ditemukan interaksi pada strata usia ibu saat hamil $>30$ tahun dan $<30$ tahun, sehingga rasio prevalens (PR) ASI eksklusif terhadap kejadian stunting adalah 0,41 IK95\% 0,23-0,74 dan 1,74 IK95\% 0,93-3,24; p Mantel-Haenszel < 0,001 secara berturut-turut. Penelitian ini menyimpulkan bahwa ASI eksklusif dapat bersifat protektif terhadap stunting bila usia ibu saat hamil > 30 tahun. Selain meningkatkan cakupan, diperlukan upaya meningkatkan kualitas ASI eksklusif untuk mengoptimalkan upaya pencegahan stunting.

Kata kunci: ASI Ekslusif, Kabupaten Bogor, stunting, usia ibu saat hamil

\author{
A B S TR A C T
}

Stunting strongly related to impaired cognitive ability and quality of life Prevalence of stunting in Indonesia is $30.8 \%$. Stunting is associated with nutritional adequacy in the $f$ irst day of life, one of which is exclusive breastfeeding. Although its coverage above $74 \%$, association between stunting and exclusive breastfeeding were inconsistent due to various quality and quantity during breastfeeding. The aim of this study is to investigate the association between exclusive breastfeeding and stunting in Kabupaten Bogor, as one of stunting endemic region in Indonesia. This study was cross-sectional study and conducted in Puskesmas Kecamatan Ciampea, Kabupaten Bogor on February to April 2019. Inclusion criteria was child aged 6-59 months who visit outpatient clinic. Exclusive breastfeeding information was obtained from structured interview, stunting status used standardized anthropometry. From 162 child, 117 (72.22\%) had received exclusive breastfeeding and 64 (39,51\%) were stunting. Multivariate analysis showed an interaction if maternal age at pregnancy $\geq$ 30 years old or $<30$ years old, with prevalence ratio (PR) of exclusive breastfeeding in stunting 0,41 95\% $\mathrm{Cl} 0,23-0,74$ and $1,7495 \% \mathrm{Cl} 0,93-$ 3,24; p Mantel-Haenszel < 0,001, respectively. The conlusion was exclusive breastfeeding might have protective effect to stunting if maternal age at pregnancy > 30 years old. Beside coverage, increasing exclusive breastfeeding quality should be the main concern to prevent stunting.

Keywords: Exclusive breastfeeding, Kabupaten Bogor, stunting, maternal age at pregnancy

\section{Pendahuluan}

Stunting, dikenal dengan perawakan pendek, didefinisikan sebagai tinggi badan lebih rendah dari -2 deviasi standar. ${ }^{1}$ Stunting yang kini menjadi masalah kesehatan global merupakan suatu dampak akhir dari malnutrisi kronik. ${ }^{2}$ Prevalensi stunting di Indonesia tahun 2018 adalah 30,8\%, ${ }^{3}$ menempati posisi lima besar di dunia. ${ }^{1, ~} 4$ Kabupaten Bogor adalah salah satu daerah tinggi kejadian stunting (140.000 balita) dengan tingkat pendidikan dan sosioek onomi yang beragam. ${ }^{5}$ Intervensi gizi pada anak stunting dapat dikatakan terlambat karena telah terjadi gangguan perkembangan otakyang menimbulkan hambatan kemampuan kognitif dan kualitas hidup di kemudian hari. ${ }^{6-8}$ Oleh karena itu, aspek pencegahan menjadi sangat penting pada penanganan stunting..$^{9,10}$

Pencegahan stunting bermula dari upaya pemenuhan nutrisi pada 1000 hari pertama kehidupan. Pada periode ini, asupan nutrisi utama diperoleh dari air susu ibu (ASI) yang diberikan secara eksklusf (6 bulan tanpa disertai asupan nutrisi dari sumber lain). Kajian biologis dan pada lingkup kesehatan masyarakat telah membuktikan bahwa kandungan nutrisi pada ASI sangat mencukupi kebutuhan tumbuh kembang anak., 6,11

*Korespondensi: Sudarto Ronoatmodjo Departemen Epidemiologi Gd A Lt 1 Fakultas Kesehatan Masyarakat Universitas Indonesia. Kampus baru UI Depok. Email sudartorono@yahoo.com 
Namun, hubungan ASI eksklusif dengan stunting seringkali ditemukan tidak konsisten. Penelitian sebelumnya menunjukkan bahwa cakupan ASI eksklusif di Kabupaten Bogor pada penderita stunting hanya 17\%.12 Beberapa penelitian terdahulu menemukan proporsi stunting yang lebih tinggi pada balita yang mendapatkan ASI eksklusif.13, 14 Prevalensi stunting diduga berkaitan dengan kualitas dan kuantitas ASI yang diberikan pada periode tersebut yang dipengaruhi oleh beberapa faktor (multifaktorial). 2, 15-17

Penelitian ini bertujuan untuk mengetahui hubungan pemberian ASI eksklusif terhadap stunting pada balita di Kabupaten Bogor. Hasil penelitian ini diharapkan mampu memberikan analisis dampak pemberian ASI eksklusif di Kabupaten Bogor sehingga pemecahan masalah stunting yang sensitif dan spesifik dapat diputuskan di kemudian hari.

\section{Metode Penelitian}

Penelitian ini menggunakan desain studi potong lintang yang dilaksanakan di Puskesmas Kecamatan Ciampea, Kabupaten Bogor, pada bulan Februari - April 2019. Kriteria inklusi adalah balita usia 6-59 bulan yang berkunjung ke poliklinik anak dan bersedia untuk menjadi subjek penelitian. Subjek dengan penyakit berat, penyakit kronis, maupun kecurigaan kelainan genetik tidak diikutsertakan pada penelitian ini. Subjek dengan berat lahir rendah (BBLR) dan prematur juga dieksklusikan. Metode pengambilan sampel penelitian ini adalah convenient sampling berdasarkan subjek yang mengunjungi puskesmas. Penelitian ini mengikuti kaidah etika penelitian berdasarkan Deklarasi Helsinki. Jumlah sampel minimum berdasarkan perhitungan uji hipotesis beda proporsi adalah 116 sampel.

Pemeriksaan antropometri meliputi berat badan dan tinggi badan dilakukan menggunakan instrumen yang terkalibrasi. Panjang badan diukur secara terlentang menggunakan papan ukur pada anak berusia kurang dari 1 tahun atau anak yang belum mampu berdiri, sementara anak berusia 1 tahun atau lebih diukur tinggi badannya dengan microtoise. Ketepatan pengukuran adalah $1 \mathrm{~cm}$ untuk tinggi badan. Setiap pemeriksaan dilakukan sebanyak tiga kali dan diambil nilai rata-rata. Stunting didefinisikan sebagai tinggi badan kurang dari -2 SD sesuai usia pada kurva WHO. Informasi mengenai ASI eksklusif serta faktor-

faktor lain yang memengaruhinya diperoleh dengan wawancara terstruktur. Orang tua pasien tidak ditanyakan secara eksplisit mengenai ASI eksklusif, tetapi digali mengenai asupan nutrisi yang diberikan sejak lahir hingga usia 6 bulan guna mencegah terjadinya bias pelaporan. ASI eksklusif didefinisikan sebagai asupan nutrisi hanya ASI selama 6 bulan pertama kehidupan, kecuali pemberian cairan pada kondisi gawat darurat atau sakit berat. Wawancara terstruktur dilakukan sebelum pemeriksaan tinggi badan untuk mencegah terjadinya observer bias.

Data ditampilkan secara deskriptif dan analitik. Ukuran epidemiologis yang digunakan adalah rasio prevalens (prevalence ratio, $P R$ ) untuk mengetahui hubungan ASI eksklusif dengan stunting. Analisis bivariat dilakukan untuk menilai hubungan setiap variabel dengan stunting. Variabel dengan nilai $p<0.25$ pada analisis bivariat akan diikutsertakan pada analisis multivariat. Analisis multivariat menggunakan cox regression dengan ukuran asosiasi rasio prevalens. Seluruh variabel dimasukan dalam model kemudian dikeluarkan satu persatu. Apabila saat suatu variabel dikeluarkan, terjadi perubahan PR ASI eksklusif terhadap stunting lebih dari 10\%, variabel tersebut dikatakan sebagai perancu (confounder) sehingga harus diikutsertakan dalam model. Analisis interaksi antarvariabel dilakukan setelah seluruh perancu diidentifikasi. Nilai $p<0.05$ dianggap signifikan secara statistik pada penelitian ini. Data dianalisis menggunakan perangkat lunak STATA 15 untuk Windows.

\section{Hasil}

Selama periode penelitian, diperoleh 162 subjek yang berpartisipasi. Proporsi stunting pada penelitian ini adalah 39,51\%. Jumlah responden laki-laki dan perempuan hampir seimbang (48,77\% dan 51,23\%), sementara subjek paling banyak pada kelompok usia 48-59 bulan. Diagnosis kerja terbanyak pada subjek adalah infeksi saluran pernapasan akut (ISPA), yakni 83,33\%. Sebanyak 117 subjek (72,22\%) diketahui mendapat ASI eksklusif. Terdapat 43,21\% keluarga yang memperoleh pendapatan kurang dari upah minimum regional (UMR) dan sebagian besar (68,52\%) ibu tidak memperoleh pendidikan 9 tahun. Data karakteristik demografis lengkap dapat dilihat pada Tabel 1.

Berdasarkan Tabel 2, stunting ditemukan pada 45 subjek (38,46\%) yang mendapat ASI Eksklusif. Meskipun lebih rendah daripada subjek yang tidak mendapat ASI Eksklusif (19 subjek, 42,22\%), analisis bivariat tidak menunjukkan hubungan antara ASI eksklusif dan stunting (PR 0,91 IK95\% 0,60-1,37). Namun, ditemukan beberapa variabel dengan tingkat kemaknaan (nilai p) <0.25, yakni jenis kelamin, kelompok usia, status gizi, waktu mulai MPASI, status imunisasi, usia ibu saat hamil, dan tinggi badan ibu. Seluruh variabel ini diikutsertakan pada analisisi multivariat untuk menyingkirkan peran sebagai perancu ataupun interaksi. 
Tabel 1. Karakteristik Subjek Penelitian

\begin{tabular}{|c|c|c|}
\hline Karakteristik & $N=162$ & $\%$ \\
\hline \multicolumn{3}{|l|}{ Perawakan } \\
\hline Stunting & 64 & 39,51 \\
\hline Normal & 98 & 60,49 \\
\hline \multicolumn{3}{|l|}{ Jenis Kelamin } \\
\hline Laki-laki & 79 & 48,77 \\
\hline Perempuan & 83 & 51,23 \\
\hline \multicolumn{3}{|l|}{ Kelompok Usia } \\
\hline $\begin{array}{l}60-11 \text { bulan } \\
12-23 \text { bulan }\end{array}$ & $\begin{array}{l}13 \\
38\end{array}$ & $\begin{array}{l}8,02 \\
23,46\end{array}$ \\
\hline 24-35 bulan & 35 & 21,60 \\
\hline 36-47 bulan & 29 & 17,90 \\
\hline 48-59 bulan & 47 & 29,01 \\
\hline \multicolumn{3}{|l|}{ Diagnosa kerja saat berkunjung } \\
\hline ISPA & 135 & 83,33 \\
\hline Gastroenteritir & 6 & 3,7 \\
\hline Infeksi kulit tidak spesifik & 7 & 4,32 \\
\hline Demam & 5 & 3,09 \\
\hline Diagnosa lain & 9 & 5,56 \\
\hline \multicolumn{3}{|l|}{ ASI Eksklusif } \\
\hline Ya & 117 & 72,22 \\
\hline Tidak & 45 & 27,78 \\
\hline \multicolumn{3}{|l|}{ Status Gizi } \\
\hline Gizi Kurang & 64 & 39,51 \\
\hline Normal & 98 & 60,49 \\
\hline \multicolumn{3}{|l|}{ Jumlah anak } \\
\hline$\leq 2$ & 127 & 78,4 \\
\hline$>2$ & 35 & 21,6 \\
\hline \multicolumn{3}{|l|}{ Urutan anak ke- } \\
\hline 1 & 71 & 43,83 \\
\hline 2 & 58 & 35,80 \\
\hline$>3$ & 33 & 20,37 \\
\hline \multicolumn{3}{|l|}{ Status Imunisasi } \\
\hline Lengkap & 124 & 76,54 \\
\hline Tidak lengkap & 38 & 23,46 \\
\hline \multicolumn{3}{|l|}{ Usia ibu saat hamil } \\
\hline$<30$ tahun & 84 & 51,85 \\
\hline$>30$ tahun & 78 & 48,15 \\
\hline \multicolumn{3}{|l|}{ Pendidikan Ibu } \\
\hline$<9$ tahun & 111 & 68,52 \\
\hline$>9$ tahun & 51 & 31,48 \\
\hline \multicolumn{3}{|l|}{ Pendapatan keluarga } \\
\hline$<$ Rp. 2.800 .000 & 70 & 43,21 \\
\hline$>$ Rp. 2.800 .000 & 92 & 56,79 \\
\hline \multicolumn{3}{|l|}{ Pengasuh } \\
\hline Orangtua & 155 & 95,68 \\
\hline Kerabat & 5 & 3,09 \\
\hline Baby sitter & 2 & 1,23 \\
\hline
\end{tabular}

Tabel 3 menggambarkan bahwa berdasarkan hasil analisis multivariat, ditemukan interaksi antara variabel ASI eksklusif dengan usia ibu (nilai $p=0.001$ ). Interaksi diketahui dengan memasukan variabel interaksi (perkalian antara variabel ASI eksklusif dengan usia ibu) dalam model multivariat. Analisis lebih lanjut dilakukan dalam strata usia ibu saat hamil < 30 tahun (Tabel 4) dan $\geq 30$ tahun (Tabel 5).

Berdasarkan hasil analisis multivariat pada kedua strata tersebut, diperoleh informasi bahwa ASI eksklusif bersifat protektif (PR 0,41 IK95\% 0,25 - 0,68) terhadap stunting apabila usia ibu saat hamil $\geq 30$ tahun setelah dikontrol variabel pemberian MPASI dan tinggi badan ibu.
Tabel 2 . Analisis bivariat faktor yang berhubungan dengan stunting pada anak usia 6- 59 bulan di Kabupaten Bogor tahun 2019

\begin{tabular}{|c|c|c|c|c|c|c|}
\hline \multirow{2}{*}{$\begin{array}{c}\text { Faktor yang } \\
\text { berhubungan }\end{array}$} & \multicolumn{2}{|c|}{ Stunting } & \multicolumn{2}{|c|}{ Tidak stunting } & \multirow[t]{2}{*}{ PR (IK95\%) } & \multirow[t]{2}{*}{ nilai $p$} \\
\hline & $\mathrm{n}$ & $\%$ & $\mathrm{n}$ & $\%$ & & \\
\hline \multicolumn{7}{|l|}{ ASI Eksklusif } \\
\hline Ya & 45 & 38.46 & 72 & 61.54 & $0.91(0.60-1.37)$ & 0.661 \\
\hline Tidak & 19 & 42.22 & 26 & 57.78 & referensi & \\
\hline \multicolumn{7}{|l|}{ Jenis Kelamin } \\
\hline Laki-laki & 36 & 45.57 & 43 & 54.43 & $1.35(0.92-1.99)$ & 0.124 \\
\hline $\begin{array}{l}\text { Perempuan } \\
\text { Kelompok Usia }\end{array}$ & 28 & 33.73 & 55 & 66.27 & referensi & \\
\hline 6-11 bulan & 2 & 15.38 & 11 & 84.62 & referensi & 0.011 \\
\hline $\begin{array}{l}12-23 \\
\text { bulan }\end{array}$ & 20 & 52.63 & 18 & 47.37 & $3.42(0.92-12.68)$ & \\
\hline $\begin{array}{l}24-35 \\
\text { bulan }\end{array}$ & 17 & 48.57 & 18 & 51.43 & $3.16(0.84-11.81)$ & \\
\hline $\begin{array}{l}36-47 \\
\text { bulan }\end{array}$ & 14 & 48.28 & 15 & 51.72 & $3.14(0.83-11.86)$ & \\
\hline $\begin{array}{l}48-59 \\
\text { bulan }\end{array}$ & 11 & 23.40 & 36 & 76.60 & $1.52(0.3806 .02)$ & \\
\hline \multicolumn{7}{|c|}{ Jumlah saudara kandung (termasuk subjek) } \\
\hline$\leq 2$ orang & 50 & 39.37 & 77 & 60.63 & $1.02(0.64-1.61)$ & 0.946 \\
\hline$>2$ orang & 14 & 40.00 & 21 & 60.00 & referensi & \\
\hline \multicolumn{6}{|l|}{ Urutan anak ke- } & 0.945 \\
\hline $\begin{array}{l}\text { Kedua } \\
\text { Ketiga dan } \\
\text { seterusnya }\end{array}$ & 22 & 37.93 & 36 & 62.07 & $0.93(0.60-1.43)$ & \\
\hline \multicolumn{7}{|l|}{ Status gizi } \\
\hline Gizi cukup & 30 & 30.61 & 68 & 69.39 & referensi & 0.004 \\
\hline Gizi kurang & 34 & 53.13 & 30 & 46.88 & $1.74(1.19-2.53)$ & \\
\hline \multicolumn{7}{|l|}{$\begin{array}{l}\text { Waktu mulai } \\
\text { MPASI }\end{array}$} \\
\hline$\leq 6$ bulan & 47 & 35.61 & 85 & 64.39 & referensi & 0.033 \\
\hline$>6$ bulan & 17 & 56.67 & 13 & 43.33 & $1.59(1.08-2.35)$ & \\
\hline \multicolumn{7}{|l|}{ Imunisasi } \\
\hline Lengkap & 45 & 36.29 & 79 & 63.71 & referensi & 0.130 \\
\hline $\begin{array}{l}\text { Tidak } \\
\text { lengkap } \\
\text { Usia ibu saat } \\
\text { hamil }\end{array}$ & 19 & 50.00 & 19 & 50.00 & $1.38(0.93-2.04)$ & \\
\hline $\begin{array}{l}<30 \text { tahun } \\
\geq 30 \text { tahun }\end{array}$ & $\begin{array}{l}39 \\
25\end{array}$ & $\begin{array}{l}46.43 \\
32.05\end{array}$ & $\begin{array}{l}45 \\
53\end{array}$ & $\begin{array}{l}53.57 \\
67.95\end{array}$ & $\begin{array}{c}\text { referensi } \\
0.69(0.46-1.03)\end{array}$ & 0.061 \\
\hline \multicolumn{7}{|l|}{ Tinggi badan ibu } \\
\hline$<145 \mathrm{~cm}$ & 10 & 62.50 & 6 & 37.50 & $1.69(1.10-2.61)$ & 0.047 \\
\hline$>145 \mathrm{~cm}$ & 54 & 36.99 & 92 & 63.01 & referensi & \\
\hline \multicolumn{7}{|l|}{$\begin{array}{l}\text { Sanitasi } \\
\text { lingkungan }\end{array}$} \\
\hline Bersih & 56 & 38.36 & 90 & 61.64 & referensi & 0.366 \\
\hline $\begin{array}{l}\text { Tidak } \\
\text { bersih }\end{array}$ & 8 & 50.00 & 8 & 50.00 & $1.30(0.77-2.22)$ & \\
\hline \multicolumn{7}{|l|}{$\begin{array}{l}\text { Kebiasaan cuci } \\
\text { tangan }\end{array}$} \\
\hline Rutin & 10 & 41.67 & 14 & 58.33 & referensi & 0.815 \\
\hline Tidak rutin & 54 & 39.13 & 84 & 60.87 & $1.07(0.64-1.79)$ & \\
\hline \multicolumn{7}{|l|}{$\begin{array}{l}\text { Pendapatan } \\
\text { keluarga }\end{array}$} \\
\hline$<$ UMR & 49 & 38.28 & 79 & 61.72 & $0.87(0.56-1.34)$ & 0.536 \\
\hline$>$ UMR & 15 & 44.12 & 19 & 55.88 & referensi & \\
\hline \multicolumn{7}{|c|}{ Lama pendidikan formal ibu } \\
\hline$<9$ tahun & 44 & 38.94 & 69 & 61.06 & $1.05(0.70-1.58)$ & 0.822 \\
\hline$>9$ tahun & 20 & 40.82 & 29 & 59.18 & referensi & \\
\hline \multicolumn{7}{|c|}{$\begin{array}{l}\text { Anggota keluarga yang } \\
\text { merokok }\end{array}$} \\
\hline Ada & 52 & 41.94 & 72 & 58.06 & $1.33(0.80-2.22)$ & 0.253 \\
\hline Tidak ada & 12 & 31.58 & 26 & 68.42 & referensi & \\
\hline
\end{tabular}


Tabel 3. Hasil analisis multivariat fakor yang berhubungan dengan stunting

\begin{tabular}{lccccc}
\hline Variabel & Koefisien & SE & PR & $95 \% C l$ & nilai p \\
\hline ASI Eksklusif & 0.8467 & 0.5107 & 1.62 & $0.87-3.00$ & 0.130 \\
Usia ibu $<30$ & 1.2092 & 0.6435 & 1.96 & $1.02-3.75$ & 0.044 \\
tahun & & & & & \\
MPASI > 7 bulan & 0.8339 & 0.4334 & 1.55 & $1.12-2.12$ & 0.007 \\
Tinggi badan ibu & 1.0697 & 0.5711 & 1.55 & $1.13-2.11$ & 0.006 \\
$<145 \mathrm{~cm}$ & & & & & \\
ASI Eksklusif x & -2.4427 & 0.7648 & 0.25 & $0.11-0.58$ & 0.001 \\
$\begin{array}{l}\text { Usia ibu }<30 \\
\text { tahun }\end{array}$ & & & & & \\
Konstanta & -1.0461 & 0.4439 & & & 0.018 \\
\hline
\end{tabular}

Tabel 4. Hasil analisis multivariat berdasarkan strata usia ibu saat hamil $<30$ tahun

\begin{tabular}{lccccc}
\hline Variabel & Koefisien & SE & PR & 95\%Cl & nilai p \\
\hline ASI Eksklusif & 0.8795 & 0.5058 & 1.67 & $0.89-3.13$ & 0.109 \\
$\begin{array}{l}\text { MPASI }>7 \\
\text { bulan }\end{array}$ & 0.4868 & 0.5581 & 1.30 & $0.79-2.14$ & 0.301 \\
$\begin{array}{l}\text { Tinggi badan } \\
\text { ibu< }<145 \mathrm{~cm}\end{array}$ & 0.6548 & 0.7136 & 1.34 & $0.75-2.41$ & 0.326 \\
\hline
\end{tabular}

Tabel 5. Hasil analisis multivariat berdasarkan strata usia ibu saat hamil $\geq 30$ tahun

\begin{tabular}{lccccc}
\hline Variabel & Koefisien & SE & PR & $95 \% \mathrm{Cl}$ & nilai $p$ \\
\hline ASI Eksklusif & -1.6937 & 0.5939 & 0.41 & $0.25-0.68$ & 0.001 \\
$\begin{array}{l}\text { MPASI > 7 bulan } \\
\text { Tinggi badan ibu }\end{array}$ & 1.2382 & 0.7210 & 2.10 & $1.36-3.24$ & 0.001 \\
$<145 \mathrm{~cm}$ & 1.5784 & 0.9969 & 1.40 & $1.29-1.61$ & 0.001 \\
\hline
\end{tabular}

\section{Pembahasan}

Penelitian ini menunjukkan bahwa ASI eksklusif tidak berhubungan dengan kejadian stunting pada balita di Kabupaten Bogor. Namun, penelitian ini menemukan suatu interaksi bahwa peran ASI eksklusif kemungkinan bersifat protektif terhadap terjadinya stunting pada ibu dengan usia lebih dari 30 tahun. Hasil ini menggambarkan bahwa peran ASI eksklusif untuk mencegah stunting memiliki dampak yang berbedabeda pada tiap kondisi di masyarakat.

Cakupan ASI eksklusif pada penelitian ini (72,2\%) tidak jauh berbeda dari hasil Riskesdas 2018, yakni $74,5 \% .{ }^{3}$ Cakupan ini sudah cukup baik mengingat penelitian ini dilaksanakan pada daerah sosioekonomi menengah kebawah dan tingkat pendidikan yang belum baik. Sementara itu, proporsi stunting pada subjek penelitian cenderung lebih tinggi daripada prevalensi nasional tahun 2018 (30,8\%) maupun prevalensi di Kabupaten Bogor (28,0\%).3, 5

Beberapa penelitian sebelumnya menunjukkan hasil yang serupa dengan penelitian ini. Analisis data Riskesdas 2010 dan 2013 pada anak usia 12-23 bulan tidak menunjukkan hubungan ASI eksklusif dengan stunting ( $p=0.147){ }^{14,18}$ Analisis lain juga menemukan bahwa ASI eksklusif justru berkaitan dengan proporsi stunting yang lebih tinggi (44.7\% vs 30.0\%). ${ }^{13}$ Sebuah studi longitudinal di Bogor tidak menunjukkan hubungan ASI eksklusif dengan stunting (HR 1.45; IK95\% 0.92 2.29). ${ }^{19}$ Temuan yang sama juga dilaporkan pada studi kasus kontrol di Kalimantan (OR 0,18; $p=0.042) .{ }^{20}$ Berbagai hasil ini kemudian diperkuat dengan hasil meta analisis yang menyatakan bahwa ASI eksklusif tidak berdampak pada stunting. ${ }^{15}$ Namun, beberapa penelitian skala besar tetap mampu menemukan hubungan protektif ASI eksklusif terhadap stunting. ${ }^{21-24}$ Diperlukan analisis mendalam untuk menelaah faktor kualitas ASI yang menyebabkan tidak ditemukannya hubungan tersebut pada beberapa populasi., 17

Beberapa peneliti menduga bahwa efek ASI eksklusif terhadap stunting bukan berasal dari aspek asupan nutrisi, melainkan dari upaya pencegahan infeksi.2, 25 Teori lain yang berkaitan adalah sebuah model dari para ahli yang menunjukkan bahwa ASI eksklusif saja tidak akan mampu menurunkan kejadian stunting, tetapi harus didukung dengan perbaikan kondisi sosioekonomi, tingkat pendidikan, masalah penyakit infeksi, dan pemberdayaan wanita. ${ }^{17,26,27}$ Pernyataan tersebut mendukung hasil dari studi ini dengan ditemukan perbedaan rasio prevalens stunting pada kalangan usia ibu $\geq 30$ tahun dan pendapatan rendah Pada penelitian ini, hubungan ASI eksklusif terhadap stunting baru terlihat pada analisis populasi ibu berusia > 30 tahun. Hal ini sejalan dengan penelitian di daerah pedesaan Indonesia dengan 2100 subjek yang menyatakan bahwa pemberian ASI eksklusif lebih tinggi pada ibu berusia lebih tua (OR 1.03; IK95\% 1.00-1.05 untuk setiap penambahan usia). ${ }^{28}$ Ibu dengan usia > 35 tahun cenderung berhasil memberikan ASI ekslusif, terlebih bila sudah memiliki anak sebelumnya ataupun pernah memberikan ASI eksklusif. ${ }^{29,} 30$

Usia ibu dapat berkaitan dengan status nutrisi ibu, tergambar dari banyaknya kekurangan energi kronis (KEK) pada ibu muda (16,7-33,5\%) dibandingkan usia diatas 30 tahun (6,5-12,3\%) berdasarkan Riskesdas 2018. ${ }^{29}$ KEK berdampak langsung terhadap komposisi ASI. ${ }^{31}$ Selain makronutrien, ${ }^{32}$ kandungan vitamin A, vitamin $B$, dan vitamin $D$ akan menurun drastis bila asupan nutrisi ibu tidak adekuat, ${ }^{33}$ begitu pula dengan kandungan besi, seng, natrium, kalium, kalsium, dan magnesium. ${ }^{34,} 35$ Oleh karena itu, ibu hamil direkomendasikan untuk mendapat asupan minimum 1800 kalori tiap harinya. ${ }^{33}$

Usia ibu juga dapat dimaknai sebagai kesiapan mental yang lebih baik untuk memiliki dan merawat anak. ${ }^{36}$ Kondisi psikologis ini sangat mempengaruhi kuantitas ASI yang diperoleh bayi, tetapi sering tidak disadari oleh ibu..$^{19}$ Meskipun begitu, tidak dapat ditarik kesimpulan bahwa usia ibu muda menandakan ketidaksiapan mental dalam memiliki anak maupun 
memberikan ASI.

Pemberian ASI eksklusifjuga tidak akan optimal bila ibu masih mengalami anemia. Anemia pada ibu hamil di Indonesia berkisar antara 25-45\%, bahkan di kota besar seperti Jakarta (11\%), ${ }^{37}$ dan cenderung lebih tinggi pada ibu hamil berusia muda. ${ }^{38}$ Sebanyak $87,6 \%$ ibu hamil pernah mendapatkan tablet tambah darah, namun hanya 37,7\% yang mengonsumsi lebih dari 90 tablet selama kehamilan. ${ }^{29}$ Ibu menyusui dengan anemia tentu akan memiliki kandungan nutrisi, terutama laktoferin, pada ASI yang rendah. ${ }^{33}$ Selaras dengan upaya pemenuhan nutrisi, risiko anemia akan menurun pada ibu dengan IMT yang tinggi. ${ }^{39}$

Dugaan penyebab tidak optimalnya ASI eksklusif pada penelitian ini adalah tingkat pendidikan rendah. Hal ini sesuai dengan berbagai penelitian sebelumnya. 9 , 40 Berdasarkan analisis data pada Riskesdas 2013 dan 2018, penyebab lain yang memengaruhi ASI eksklusif adalah k ondisi sosioekonomi dan kualitas asuhan antenatal. ${ }^{41}$ Kualitas antenatal ini berkaitan dengan persepsi ibu yang kemudian meningkatkan keberlangsungan ASI eksklusif (OR 1.60; IK95\% 1.19-2.17). ${ }^{28}$ Selain itu, hambatan ASI eksklusif di Indonesia antara lain adalah pengetahuan ibu, kualitas dan kuantitas ASI eksklusif, kurangnya political will dari pemerintah, serta promosi susu formula yang tidak dibatasi. ${ }^{42}$

Namun, perlu ditekankan bahwa ASI eksklusif bukanlah satu-satunya aspek nutrisi yang perlu diperhatikan dalam pencegahan stunting. Pemberian makanan pendamping ASI (MPASI) perlu diperhatikan, baik dari waktu yang tepat untuk memulai hingga komposisi yang sesuai, sebagai sarana pemenuhan nutrisi pada anak, bahkan sebelum usia 6 bulan. ${ }^{16}$

Penelitian ini merupakan studi potong lintang sehingga tidak dapat menyimpulkan hubungan sebab akibat yang kuat. Dibutuhkan suatu penelitian kohort prospektif untuk mengetahui dampak ASI eksklusif terhadap stunting dengan memperhatikan kualitas pemberian ASI, kuantitas pemberian ASI, serta kaitan dengan faktor sosioekonomi untuk menemukan model yang tepat mengenai kaitan ASI eksklusif terhadap stunting. Selain itu, dibutuhkan suatu pendekatan kualitatif untuk menjelaskan tidak adanya hubungan antara stunting dengan ASI eksklusif pada ibu dengan usia $<30$ tahun.

\section{Kesimpulan}

Secara umum, ASI eksklusif tidak berkaitan dengan kejadian stunting pada anak usia 6-59 bulan di Kabupaten Bogor. Namun, terdapat kemungkinan efek protektif ASI eksklusif terhadap stunting pada kelompok usia ibu saat hamil $\geq 30$ tahun. Peran ASI eksklusif dalam pencegahan stunting sangat bergantung pada faktor pendukung lain. Selain meningkatkan cakupan, diperlukan upaya meningkatkan kualitas pemberian ASI eksklusif untuk mencegah terjadinya stunting di kemudian hari.

\section{Referensi:}

1. Bhutta ZA. Global child nutrition and the Sustainable Development Goals. The Lancet Child \& Adolescent Health. 2017;1(4):256-7.

2. Black RE, Victora CG, Walker SP, Bhutta ZA, Christian P, de Onis $M$, et al. Maternal and child undernutrition and overweight in low-income and middle-income countries. Lancet. 2013;382(9890):427-51.

3. Indonesia KKR. Hasil Utama Riskesdas 2018. Jakarta: Kementerian Kesehatan Republik Indonesia; 2018.

4. WorldBank. Joint Child Malnutrition Estimates. UNICEF/WHO/ World Bank May 2018 edition.

5. Kemiskinan TNPP. 100 Kabupaten/ Kota Prioritas untuk Intervensi Anak Kerdil (stunting). Jakarta: Sekretariat Wakil Presiden Republik Indonesia; 2017.

6. de Onis M, Branca F. Childhood stunting: a global perspective. Matern Child Nutr. 2016;12(S1):12-26.

7. Cueto S, León J, Miranda A, Dearden K, Crookston BT, Behrman JR. Does pre-school improve cognitive abilities among children with early-life stunting? A longitudinal study for Peru. International Journal of Educational Research. 2016;75:102-14.

8. Casale D, Desmond C. Recovery from stunting and cognitive outcomes in young children: evidence from the South African Birth to Twenty Cohort Study. J Dev Orig Health Dis. 2016;7(2):163-71.

9. Beal T, Tumilowicz A, Sutrisna A, Izwardy D, Neufeld LM. A review of child stunting determinants in Indonesia. Matern Child Nutr. 2018;14(4):e12617.

10. Bloem MW, de Pee S, Le Hop T, Khan NC, Laillou A, Minarto, et al. Key Strategies to Further Reduce Stunting in Southeast Asia: Lessons from the ASEAN Countries Workshop. Food Nutr Bull. 2013;34(2_suppl1):S8-S16.

11. Bashiardes S, Thaiss Christoph A, Elinav E. It's in the Milk: Feeding the Microbiome to Promote Infant Growth. Cell Metab. 2016;23(3):393-4.

12. Ernawati F RY, Permanasari Y. Pengaruh asupan protein ibu hamil dan panjang badan bayi lahir terhadap kejadian stunting pada anak usia 12 bulan di kabupaten bogor. Penel Gizi Makan. 2013;36(1).

13. Rachmi CN, Agho KE, Li M, Baur LA. Stunting, Underweight and Overweight in Children Aged 2.0-4.9 Years in Indonesia: Prevalence Trends and Associated Risk Factors. PLOS ONE. 2016;11(5):e0154756.

14. T italey CR Al, Hapsari D, Muasyaroh A, Dibley MJ. Determinants of the stunting of children under two years old in indonesia: a multilevel analysis of the 2013 indonesia basic health survey. Nutrients. 2019;11(5).

15. Giugliani ER, Horta BL, Loret de Mola C, Lisboa BO, Victora CG. Effect of breastfeeding promotion interventions on child growth: a systematic review and meta-analysis. Acta Paediatr. 2015;104(467):20-9.

16. Vandenplas Y HB, Basrowi RW. Breastfeeding is best. But what after breastfeeding? W Nutr J. 2018. 
17. Bhutta ZA, Ahmed T, Black RE, Cousens S, Dewey K, Giugliani $\mathrm{E}$, et al. What works? Interventions for maternal and child undernutrition and survival. Lancet. 2008;371(9610):417-40.

18. Aryastami NK, Shankar A, Kusumawardani N, Besral B, Jahari $A B$, Achadi $E$. Low birth weight was the most dominant predictor associated with stunting among children aged 12-23 months in Indonesia. BMC Nutrition. 2017;3(1):16.

19. Utami NH RR, Irawati A, Sari K, Rosha BC, Amaliah N, Besral. Short birth length, low birth weight, and maternal short stature are dominant risks of stunting among children aged 0-23 months: evidence from bogor longitudinal study on child growth and development, Indonesia. Mal J Nutr. 2018;24(1):11-23.

20. Sugiyanto J RS, Dewi YLR. The effects of exclusive breastfeeding and contextual factor of village on stunting in bontang, east kalimantan, indonesia. J Epid Pub Health. 2019;4(3):222-33.

21.D A. The effect of breast milk toward children's growth: a systematic review. Int J Health Life Sci. 2017;3(1).

22. Akseer N, Al-Gashm S, Mehta S, Mokdad A, Bhutta ZA. Global and regional trends in the nutritional status of young people: a critical and neglected age group. Ann N Y Acad Sci. 2017;1393(1):3-20.

23. Vaivada T, Gaffey MF, Das JK, Bhutta ZA. Evidence-based interventions for improvement of maternal and child nutrition in low-income settings: what's new? Curr Opin Clin Nutr Metab Care. 2017;20(3):204-10.

24. Gupta PM, Perrine CG, Chen J, Elam-Evans LD, Flores-Ayala R. Monitoring the World Health Organization Global Target 2025 for Exclusive Breastfeeding: Experience From the United States. J Hum Lact. 2017;33(3):578-81.

25. Sinha B, Taneja S, Chowdhury R, Mazumder S, RongsenChandola T, Upadhyay RP, et al. Low-birthweight infants born to short-stature mothers are at additional risk of stunting and poor growth velocity: Evidence from secondary data analyses. Matern Child Nutr. 2018;14(1):e12504.

26. Dewey KG. Reducing stunting by improving maternal, infant and young child nutrition in regions such as South Asia: evidence, challenges and opportunities. Matern Child Nutr. 2016;12(S1):27-38.

27. Lo Bue MC, Priebe J. Revisiting the socioeconomic determinants of exclusive breastfeeding practices: evidence from Eastern Indonesia. Oxford Development Studies. 2018;46(3):398-410.

28. Belvedere LM AR, Smith R, Thomas $K$, Sever T, Syafiq A, et al. Barriers to Optimal Breastfeeding in Rural Indonesia. Arch Epidemiol. 2018;124.

29. Kitano N, Nomura K, Kido M, Murakami K, Ohkubo T, Ueno $M$, et al. Combined effects of maternal age and parity on successful initiation of exclusive breastfeeding. Preventive Medicine Reports. 2016;3:121-6.

30. Bai DL, Fong DYT, Tarrant M. Previous Breastfeeding Experience and Duration of Any and Exclusive Breastfeeding among Multiparous Mothers. Birth. 2015;42(1):70-7.
31. Fikawati S SA. Maternal calorie intake is a significant factors associated with 6 months of exclusive breastfeeding among lactating mothers in Depok City, Indonesia. Mal J Nutr. 2017;23(1):31-41

32. Khodabakhshi A, Mehrad-Majd H, Vahid F, Safarian M. Association of maternal breast milk and serum levels of macronutrients, hormones, and maternal body composition with infant's body weight. Eur J Clin Nutr. 2018;72(3):394400.

33. Ares Segura S, Arena Ansótegui J, Marta Díaz-Gómez N. The importance of maternal nutrition during breastfeeding: Do breastfeeding mothers need nutritional supplements? Anales de Pediatría (English Edition). 2016;84(6):347.e1-.e7. 34.Mane SM PN, Nerurkar AV. Study of effect of maternal nutrition on breast milk trace elements in malnourished versus well-nourished mothers. Int J Adv Med. 2018;5(5):1234-9.

35. Bravi F, Wiens F, Decarli A, Dal Pont A, Agostoni C, Ferraroni M. Impact of maternal nutrition on breast-milk composition: a systematic review. The American Journal of Clinical Nutrition. 2016;104(3):646-62.

36. Mangrio E, Persson K, Bramhagen A-C. Sociodemographic, physical, mental and social factors in the cessation of breastfeeding before 6 months: a systematic review. Scand J Caring Sci. 2018;32(2):451-65.

37. S B. Maternal micronutrient def iciency during the $f$ irst trimester among indonesian pregnant women living in jakarta. eJKI. 2016;4(2):76-81.

38. Cicih O, Lelly A. Young Mothers, Parity and the Risks of Anemia in the Third Trimester of Pregnancy. Health Science Journal of Indonesia. 2015;6(1):7-11.

39. Mocking M, Savitri Al, Uiterwaal CSPM, Amelia D, Antwi E, Baharuddin $M$, et al. Does body mass index early in pregnancy influence the risk of maternal anaemia? An observational study in Indonesian and Ghanaian women. BMC Public Health. 2018;18(1):873.

40. Sari M, de Pee S, Bloem MW, Sun K, Thorne-Lyman AL, Moench-Pfanner $R$, et al. Higher Household Expenditure on Animal-Source and Nongrain Foods Lowers the Risk of Stunting among Children 0-59 Months Old in Indonesia: Implications of Rising Food Prices. The Journal of Nutrition. 2009;140(1):195S-200S.

41. Sebayang SK, Dibley MJ, Astutik E, Efendi F, Kelly PJ, Li M. Determinants of age-appropriate breastfeeding, dietary diversity, and consumption of animal source foods among Indonesian children. Matern Child Nutr.n/a(n/a):e12889.

42. Flaherman VJ, Chan S, Desai R, Agung FH, Hartati H, Yelda $F$. Barriers to exclusive breast-feeding in Indonesian hospitals: a qualitative study of early infant feeding practices. Public Health Nutr. 2018;21(14):2689-97. 